\title{
DISTRIBUTION OF LAMPROITE PATHFINDERS IN SURFACE SOILS.
}

\author{
Muggeridge, Maureen T.
}

Moonstone Mines N.L., 251-257 Hay Street, East Perth, Western Australia 6004.

\section{INTRODUCTION}

Using data from orientation surveys carried out in the monsoonal Kimberley Region of Western Australia at certain known lamproite localities (Fig.1), the limitations and potential of loam, anthill and geochemical sampling in diamond exploration are considered. Lamproites referred, to occur in flat geomorphic settings and are described in detail in Jaques et al. (1986). From this limited study, some general conclusions about sampling surface materials can be drawn, but expanded surveys are needed to obtain a thorough understanding of the distribution of diamond pathfinders in the surface environment and establish sound guidelines for exploration practice.

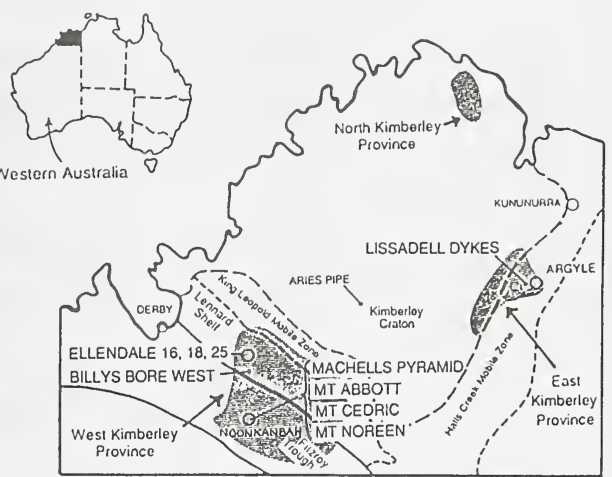

FIGURE 1 Location of Lamproites

\section{ENVIRONMENTAL VARIABLES}

In order to assess the effectiveness of loam and geochemical sampling, various agents that control the environment containing primary host rocks of diamona must be considered. Some. of these factors may assist the survival and distribution of kimberlitic (i.e. any potentially diamond-bearing) material at the surface, whilst others have the opposite effect. In general, if degradation is occurring in the host terrain, a kimberlitic body is likely to be disintegrating and shedding debris into the overlying soil and local drainage. If aggradation is taking place, accumulation of alluvium may bury the body in such a fashion as to substantially reduce its surface expression. When burial is relatively rapid and or particularly deep the kimberlitic intrusive may be totally masked with scant mineralogical or geochemical expression in the upper soil horizon. Ant activity may, in certain cases, assist in maintaining detectable geological indicators at surface levels.

\section{METHODS}

Samples were collected from soil or anthills over lamproite bodies and at varying distances from their perimeters along traverse lines.

LOAM SAMPLES

The uppermost $1 \mathrm{~cm}$ of top-soil was collected for loam samples; where gravel debris was present samples were screened at $2 \mathrm{~mm}$. The size of samples collected varied. Therefore, for comparative purposes, loam sample results in Table 1 have been standardized to "number of indicators per $\mathrm{kg}$ of sample screened at minus $2 \mathrm{~mm}$ ". Where practical, samples were taken at sites with the minimum of obvious disturbance from prior exploratory excavation which may have unnaturally increased the indicator content at surface. Loam samples were reduced to their heavy mineral component by Wilfley Table, heavy liquid and magnetic separation treatment and then examined for kimberlite/ lamproite indicator mineral content. ANTHILL SAMPLES

The largest available anthill was selected, assuming a relationship between size and depth of ant excavation. The uppermost, latest built part of the anthill was sampled, as well as some anthill "scree" around its base. Anthill samples were processed in the same manner as for loam samples. GEOCHEMICAL SAMPLES

Geochemical analysis was performed on material from many of the loam sample sites (Table 1). Samples were analysed for a range of elements associated with lamproites and kimberlites, including incompatible elements and those of ultramafic affinity. Two samples from the Ellendale area were collected to assess the geochemical background.

\section{RESULTS}

Heavy mineral and geochemical analysis results are given in Table 1. HEAVY MINERAL RESULTS

The dominant indicator minerals are chromite and phlogopite, the former having the most frequent occurrence in samples, i.e. the best overall dispersion. Pyrope occurs in some samples from Ellendale No.18, Mount Abbott, Mount Noreen and Mount Cedric. Some samples from Mount Noreen contain potassic richterite, lamproitic diopside and chrome diopside, the latter also occurring in a sample from Mount Abbott. 
Where the $0.3-0.4 \mathrm{~mm}$ size range was analysed in addition to the $0.4-2 \mathrm{~mm}$ size, the recovery of indicator minerals is at least doubled in all cases where more than one indicator grain is present in the coarser fraction.

Ellendale No.25, with a sandy overburden of $7 \mathrm{~m}$, yielded no indicators in either loam or anthill sample. Ellendale No.18, under $6 \mathrm{~m}$ overburden, yielded some chromite in both samples, but pyrope only in the anthill sample. By comparison to the loam sample, a relatively small proportion of phlogopite is present in the anthill sample from Ellendale No.16, though the chromite content is similar. At Billys Bore west the ants' haul of phlogopite is similarly low by comparison to the loam sample.

Mount Abbott, Mount Noreen and Mount Cedric yielded significant proportions of indicator minerals in central and peripheral zones over the bodies, with a rapid, steady tailing off of indicator content away from the margins. At Mount Noreen, however, there is a sudden increase in indicator levels $250 \mathrm{~m}$ south of its margin, possibly due to a local concentrating effect or an underlying, undiscovered lamproite body.

Samples from Machells Pyramid and Lissadell Road Dykes yielded only trace quantities of indicators. A further 3 chromites were obtained from one Lissadell sample by examining the $0.1-0.3 \mathrm{~mm}$ size range.

GEOCHEMISTRY RESULTS

Most lamproites in this study show anomalous Mg, P, Ti, Ni, Sr, Zr, Ba and La in the overlying or nearby soils. Elements $\mathrm{K}, \mathrm{Ca}, \mathrm{Cu}, \mathrm{Zn}, \mathrm{Rb}, \mathrm{Nb}, \mathrm{Ce}$ and $\mathrm{Nd}$ are anomalous at or near some bodies. Values of several times background are obtained for some samples. Li, Co, SC, V, Cr, Y, Mo and Th give rare or more subtle variance from background. The dispersion halo of anomalous elements around the lamproites sampled is in no case extensive, distances from the periphery not exceeding the breadth of the body, in agreement with findings of Haebig \& Jackson (1986). At Mount Noreen, anomalous values for most elements occur around $250 \mathrm{~m}$ south of the known intrusion, at a point where indicator levels are also exceptionally high. As the extent of dispersion appears abnormal, the case for a concealed lamproite here is considerably strengthened.

\section{DISCUSSION AND CONCLUSIONS}

Remote sensing and geophysical techniques have serious limitations in that anomalous responses are unqualified. Additionally, the most broadly applied of these methods, magnetics, is relatively insensitive to pyroclastic phases and, when the host environment is strongly magnetic, to kimberlitic rocks in general. Some conclusive indication at surface of the presence of a concealed kimberlitic body is extremely important when prospecting for diamonds. Sampling of surface soils is thus a valuable prospecting tool. For optimum results, however, it must be applied with discrimination and sound understanding of environmental influences.

This limited survey has the following implications, which need substantiation by further investigations:-

1. Indicator mineral yield is increased significantly by examining the grain size range below $0.4 \mathrm{~mm}$.

2. Dispersion halos, even for large exposed bodies, and especially where overburden masks the intrusion, may extend only a few hundred metres beyond the margin. Therefore, when planning loam and geochemical sampling programmes, careful consideration should be given to choosing the appropriate sampling interval.

3. Anthill samples, in this study, did not yield higher quantities of indicators than loam samples. Total reliance on anthill samples alone is therefore inadvisable. Ants appear to selectively excavate certain minerals. This may be useful in certain cases and requires investigation.

4. Geochemical analysis of a broad selection of elements should increase the chance of detecting a concealed diamond host rock.

Particular indicators known to survive well in the soil horizon may be relatively uncommon in the host rock. Possible variations in source mineralogy that will have a bearing on the types and concentrations of indicators in associated soils should be considered when planning exploration surveys and assessing loam and geochemical results.

Correct selection of the type, size, spacing and treatment of surface samples for diamond exploration depends upon an understanding of the distribution of diamond pathfinders in regolith. Detailed, broad-based studies involving all known diamond lithologies and a variety of environmental settings are needed to determine reliable sampling methods for diamond exploration.

\section{REFERENCES}

Haebig, A.E., and Jackson, D.G. (1986) Geochemical expression of some West Australian kimberlites and lamproites. Fourth International Kimberlite Conference, Perth, Extended Abstracts Volume, Geological Society of Australia $16,466-468$.

Jaques, A.L., Lewis J.D., and Smith, C.B. (1986) The kimberlitic and lamproitic rocks of Western Australia. Bulletin of the Geological survey of Western 


$\begin{array}{ll}* & \text { " } \\ 8 & 8 \\ \circ & 8 \\ 5 & 8 \\ 8 & 8\end{array}$

จุष्ष \& \& ำㅇ $a=$ gar a응 Ooo on

รกะ ำ

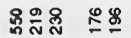

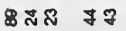

and na

สำ ชูำ

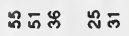

-

$0 \infty 000$

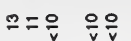

포을

$\bar{v} \quad \bar{v}-$

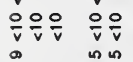

ห马า 뜨

ธาก 으

$0 \infty \infty 00$

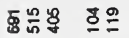

వ్ㅉำ

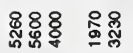

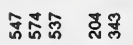

สำำำ ํㅜำ

오ำำ

ำํํำ 뜨음

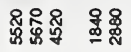

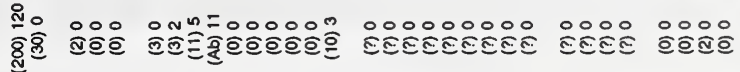

ชู\&্ৰ \& \&

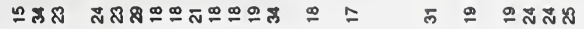

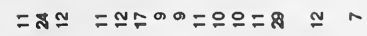

$\simeq \cong \cong \underline{\simeq}$

ทุษ

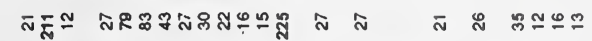

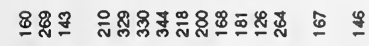

8. ำำำ

ชำ

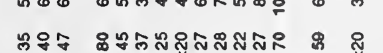

- 0 ind

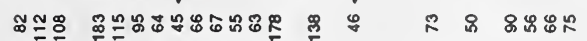

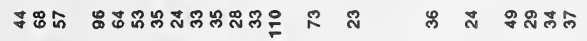

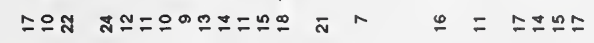

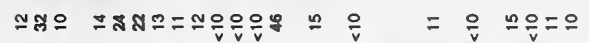
늄워

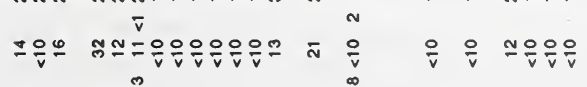

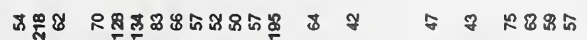
กสุ $=R=$ ㄴ=ニニニRIAR

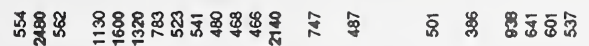

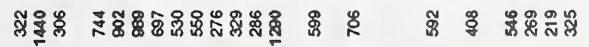

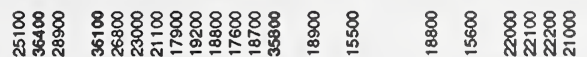

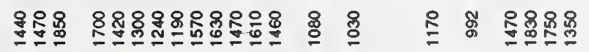

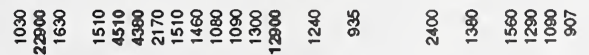

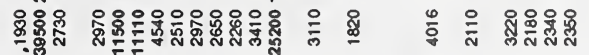

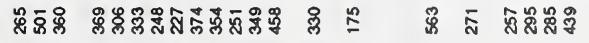

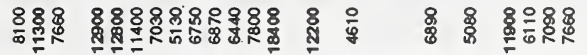
भ.

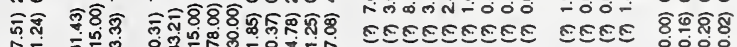

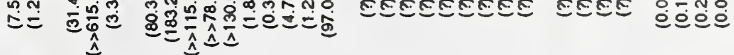

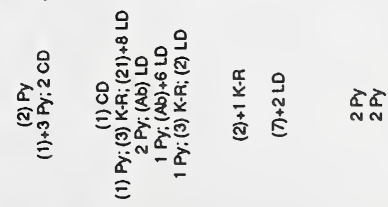
产

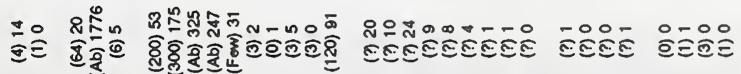

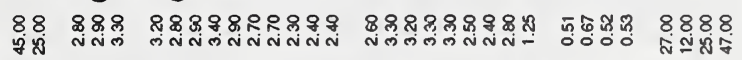

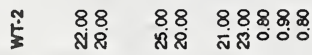
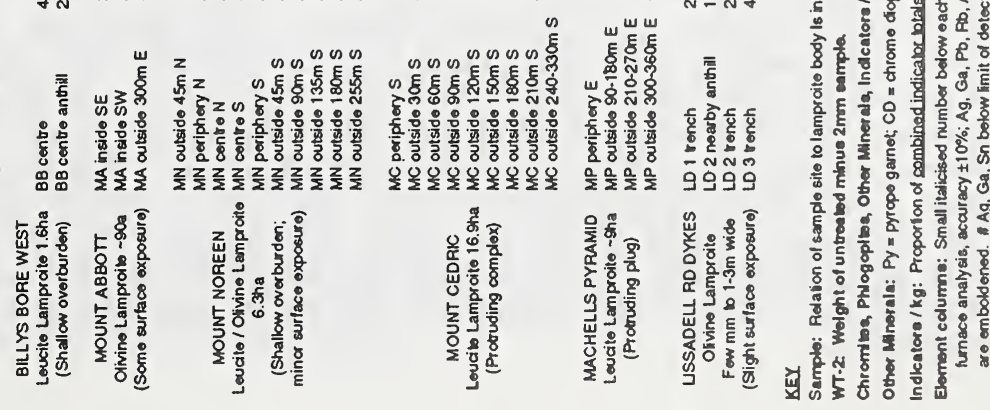

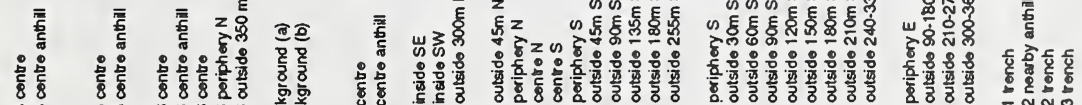

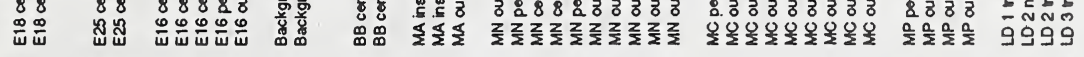

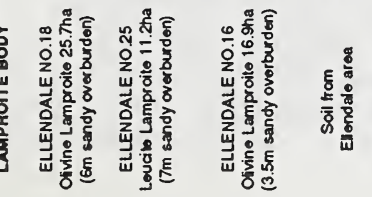

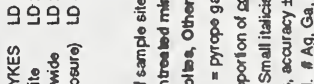

